\title{
O Sócrates de Hannah Arendt
}

\author{
Augusto Bach ${ }^{1}$ \\ Juliano Orlandi ${ }^{2}$
}

\begin{abstract}
Resumo: Com o fito de compreender as noções de história e juízo político, este artigo pretende mostrar a peculiar interpretaçấo que Hannah Arendt faz da mais conhecida e discutida personalidade filosófica: Sócrates. Assim como outras ideias, tais como a de banalidade do mal, a natureza do terror totalitário e de espaço público, sua estrita pintura do filósofo grego nos demanda a tarefa de discriminar a diferença entre pensamento e ação. Seria acaso o juízo a ponte entre as atividades de pensamento e da ação política? A preocupação, neste ensaio, é a de mostrar como Hannah Arendt estava procurando por um modo autêntico de filosofia política, cujo maior exemplo seria Sócrates. No mesmo sentido, também se debruça acerca do significado do juízo reflexionante, ideia bastante fecunda em sua obra que permanece ainda bastante alusiva.
\end{abstract}

Palavras-chave: Política. Arendt. Filosofia. História.

\section{INTRODUÇÃo}

Costuma-se afirmar que uma das maiores contribuiçóes ao pensamento político contemporâneo possa ser encontrada nas reflexôes de Hannah Arendt a respeito da faculdade do juízo. Ocupada em seus últimos anos de vida com essa temática, sua teoria teimou, não obstante, em permanecer inacabada. Diante de todas as atividades inerentes à vida do espírito, o julgar ocuparia um lugar primordial para a compreensão de suas proposições, assim como uma

1 Professor Associado do Departamento de Filosofia da Universidade Estadual do Centro-Oeste (Unicentro), Guarapuava, PR - Brasil. (iD) http://orcid.org/0000-0003-2137-5787 E-mail: augustobach@yahoo.com.br

Doutor em Filosofia pela Universidade Federal de São Carlos (UFSCar), São Carlos, SP - Brasil.

2 Professor Adjunto do Departamento de Filosofia da Unicentro, Guarapuava, PR - Brasil. (D) http:// orcid.org/0000-0003-0983-0417 E-mail: juliano_orlandi@yahoo.com.br

Doutor em Filosofia pela UFSCar.

http://dx.doi.org/10.1590/0101-3173.2019.v42n4.11.p201

This is an open-access article distributed under the terms of the Creative Commons Attribution License. 
posição pouco afeita à conceitualização imediata de sua obra. Conjectura-se que a razão para essa dificuldade resida no fato de seus escritos não apresentarem um argumento logicamente unificado - tal qual o exercício contemplativo do pensamento nos poderia fornecer, mediante seus padróes de consistência -, desdobrando-se antes como uma descrição fenomenológica das ocupaçóes do espírito, a qual privilegia determinadas facetas num dado momento de sua exposição, em detrimento de outras, deixando invariavelmente para mais tarde a tarefa de lidar com os resíduos de seu próprio trabalho. Criteriosamente, Hannah Arendt se permitiu guiar por sua experiência pessoal e histórica, fazendo da contingência o parti pris de suas indagaçôes. Talvez por isso mesmo ela jamais tenha encarado seu empenho intelectual como a realizaçáo de uma obra filosófica fechada, um sistema. Em seu modo de usar a palavra, os efeitos visados demonstram sempre uma independência refletida em relação a outrem, sem jamais incorrer em servidão a valores ou princípios já estabelecidos. Daí o efeito de liberdade que procurava proporcionar, em seu leitor. Embora tenha se formado em filosofia, ela sempre fez questão de se desassociar daqueles que fizeram do pensamento uma profissáo que lhes permitisse distanciar-se dos afazeres mundanos. Fechados assim para o que de novo venha se manifestar, eles aniquilam aquilo que, para Arendt, figurava como o único motivo para se pensar.

Enquanto a postura filosófica privilegia a conquista de um ponto de vista universal e necessário, em sua ânsia de legislar sobre o verdadeiro e o belo, ela preferiu se importar com o lado náo fundamentado de nossos conceitos e de nossa tradição de pensamento político. Se ora é de praxe o pensamento nos possibilitar uma conquista de coerência, o juízo, por outro viés, aponta para uma particularidade que jamais pode ser esgotada da mesma maneira. $\mathrm{Na}$ impossibilidade de sustentar uma formulação cabal acerca da questão reflexiva do juízo isenta dos mal-entendidos inerentes à esfera política, muitas de suas ponderaçóes permaneceram em estado de stand by, à espera de ato ulterior de acabamento. Tal foi a razão de ela, sem demora, ter-se desabonado do título de filósofa e ser costumeiramente conhecida como cientista política.

Afora isso, acreditamos que sua obra não poderá ser compreendida sem se levar em conta, além de sua suspeita, o seu profundo comprometimento com a filosofia, no âmbito da reflexão pública. Se, de acordo com suas análises, o fio da tradição sofreu uma ruptura com os acontecimentos políticos do século XX e não pode ser reatado, nem por isso a metafísica deixa de esconder um possível tesouro para o pensamento. Não é à toa que o conflito entre a filosofia 
e a política, entre o filósofo profissional e o cidadão, bem como a distinção entre pensamento e ação que animam sua obra inteira, permaneça como um divisor de águas interpretativo de seu empreendimento.

Com efeito, essa relação de mútua oposição entre filosofia e política não deixa de estar comprometida com a premissa arendtiana de que o pensamento demanda uma retirada do mundo, na solidáo socrática de "um diálogo interno entre eu e mim mesmo", enquanto a ação toma seu lugar no mundo em concerto com outros. Seguindo o leitmotiv iluminista proposto por Aren$\mathrm{dt}$, será nosso objetivo neste paper compreender o papel dedicado à figura de Sócrates como homem cuja vida fora reservada ao pensamento. Tendo como base essas questóes, este artigo tentará, ao mesmo tempo, esclarecer o papel que a função do juízo ocupa em seu empreendimento, mediante uma análise da faculdade de pensar; em vista de explorar uma tensão não suficientemente resolvida pelo seu próprio pensamento.

\section{A possível RECONCILIAÇÃo ENTRE A FILOSOFIA E A POLÍTICA}

Estou na mais completa solidão do ser que é amado e não ama, me ajude a conhecer a verdade; a respeitar meus irmãos e a amar quem me ama.

(Cazuza, Filho único)

Dado o grau de corrosão da arqueologia da modernidade sustentada por Arendt parecer estar mais propenso a compreender a história do que lançar o fundamento de uma nova filosofia política, imaginamos a contrario que já existam ao menos alguns de seus pré-requisitos. ${ }^{3}$ Entre eles, a reformulação do significado de uma pluralidade em que a relação entre verdade e liberdade é extraída diretamente da esfera dos temas e feitos humanos. Pois bem, mais do

\footnotetext{
${ }^{3}$ Passemos, então, a observar como o empreendimento de Hannah Arendt começa por se associar ao mote socrático de argumentação e a uma posição genuinamente filosófica: "Muitos dos pré-requisitos para uma nova filosofia política - que muito provavelmente consistirá na reformulação da atitude do filósofo como ser político ou da relação entre pensamento e ação - já existem, ainda que possam, à primeira vista, ter a aparência de mais uma eliminação dos obstáculos tradicionais do que a fundação de novas bases. [...] Mas... são apenas pré-requisitos. Uma autêntica filosofia política não poderá, em última instância, surgir a partir de uma análise de tendências, acomodaçôes parciais, interpretaçôes, ou, pelo contrário, da revolta contra a própria filosofia. Ela só poderá brotar de um ato original de thaumadzein, cujo impulso de admiração e questionamento deverá desta vez (isto é, contra os ensinamentos dos antigos) aprender diretamente a esfera dos assuntos humanos." (ARENDT, 2004, p. 89).
} 
que isso, talvez um aspecto prospectivo ao pensamento tenha sido recuperado por Arendt, quase que paradoxalmente, através da figura de Sócrates. ${ }^{4}$ Aqui e acolá, em alguns de seus ensaios, podemos observar intermitentemente uma interpretação bastante simpática de sua atividade, a qual reconcilia a filosofia com a política. Senão, vejamos:

$\mathrm{O}$ ponto em questão, dentro de nosso contexto, não é apenas que o pensamento devesse imperar sobre a ação, prescrevendo-lhe princípios de tal maneira que as regras da açáo fossem invariavelmente derivadas de experiências do pensamento; é que, por meio dos bioi, da identificaçáo de atividades como modos de vida, o princípio de governo se estabelecia igualmente entre homens. Historicamente, isto tornou-se o selo da filosofia da escola socrática, e a ironia desse processo provavelmente está em que era precisamente essa dicotomia entre pensamento e ação o que Sócrates temia e tentou impedir na polis. (ARENDT, 2003, p. 156-157).

Se Sócrates, um cidadão da democracia ateniense, servira ao discípulo e filósofo Platão como modelo de ßíoc $\theta \varepsilon \omega \rho \eta \tau$ tıóc (bios theōrētikós), nem por isso Hannah Arendt irá creditar ao $\delta a i ́ \mu \omega v$ (daimōn) socrático, ao seu $\bigotimes \rho \circ \varsigma$ (éros) propriamente dito, a responsabilidade pela dicotomia entre pensamento e ação. Pelo contrário, Sócrates protagonizaria historicamente o último momento - prévio à tradição de pensamento político - no qual o homem de ação e o homem de pensamento ainda não se divorciam. O ineditismo de sua leitura dos diálogos platônicos, sejam estes aporéticos, sejam de maturidade, consiste em problematizar a leitura que Platão operou da postura de Sócrates, pois, para ela, apesar de invisível, a atividade do pensamento socrático não deixava jamais de irromper no mundo fenomênico das aparências. Sócrates, como nos recorda Hannah Arendt, valeu-se para tanto da metáfora do vento, ao explicar aos seus pares o impacto físico de sua atividade de pensar, fazendo com que eles assim sentissem sua aproximação bem como os aspectos conativos de sua linguagem. E se, por isso mesmo, a experiência filosófica do

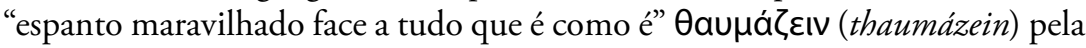
primeira vez em nossa cultura pôde ser tributada a sua figura, o mesmo não se poderá dizer do prolongamento artificial dessa admiração amorosa, operado

\footnotetext{
4 "Proponho usar como nosso modelo um homem que realmente tenha pensado sem se tornar um filósofo, um cidadão entre cidadãos, alguém que não tenha feito ou reivindicado nada além daquilo que, na sua opiniáo, todo cidadão devesse fazer e tivesse direito a reivindicar. Vocês terão adivinhado que pretendo falar sobre Sócrates, e espero que ninguém venha a contestar seriamente que minha escolha não seja historicamente justificável.” (ARENDT, 2004, p. 236).
} 
pela escrita de Platão, numa cadeia de razóes que se orienta em direção ao mundo das ideias eternas e de contemplação muda. ${ }^{5}$

Dado que a última coisa desejada pela dialética, presente na fala de Sócrates, era justamente sua fixação em um ponto de vista único e transcendente, pelo qual pudesse julgar contemplativamente a esfera das açóes humanas, seu

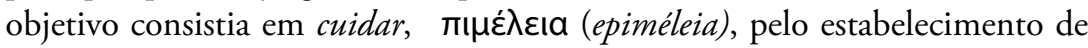
um mundo comum cuja imanência seria construída sobre a compreensão e a amizade. Dessa forma, não deixamos de encontrar en passant uma analogia do Sócrates de Hannah Arendt com as análises que ela passa a operar, na mesma época, do juízo reflexionante kantiano ligado a uma mentalidade alargada e a um senso comum estético. ${ }^{6}$ No que tange à conduta socrática em meio ao agonístico amor de prestígio e favores exercido entre seus pares, era necessário fazer com que a imagem mental que as demais pessoas pudessem ter da posição de alguém na sociedade representasse pelo menos a situação verdadeira em que se encontravam. Destarte, por afastado que estivesse da destruição da

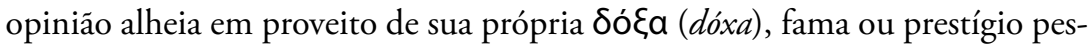
soal, a postura de Sócrates não pode ser resumida a um sofístico jogo de soma zero com seus ouvintes, na medida em que ele não é interpretado por Arendt como um mero sofista, ou como um pensador profissional, a partir de uma perspectiva stricto sensu platônica.

Cabe aqui recordarmos como em muitos textos, salvo raras exceçóes ${ }^{7}$, Arendt apresenta Sócrates como um pensador dialógico, político por excelên-

\footnotetext{
5 "Esse perigo surgiu com o início de nossa grande tradição filosófica, com Platão, e, em menor proporção, com Aristóteles. O filósofo, por demais cônscio, pelo julgamento de Sócrates, da incompatibilidade inerente das experiências filosóficas fundamentais com as experiências políticas fundamentais, generalizou o choque inicial e iniciador de thaumadzein. A posiçâo de Sócrates perdeu-se nesse processo, não porque Sócrates não houvesse deixado escritos, ou porque Platão propositalmente os distorcesse, mas porque os insights socráticos, nascidos de uma relação ainda intacta com a política e também com a experiência especificamente filosófica, perderam-se. [...] Platão propôs prolongar indefinidamente o espanto mudo que existe no início e no fim da filosofia. Tentou transformar em modo de vida (bios theôretikos) o que só pode ser um momento fugaz; ou, tomando a própria metáfora de Platão, a faísca que resulta do atrito entre suas pedras. Nessa tentativa, o filósofo se estabelece, baseia sua inteira existência naquela singularidade que experimentou quando foi acometido pelo pathos de thaumadzein. Com isso, o filósofo destrói dentro de si a pluralidade da condição humana." (ARENDT, 1987, p. 113-114).

${ }^{6}$ Cf. Sétima liçâo das LFPK (ARENDT, 1993b).

${ }^{7}$ Exceçôes tais como Verdade e política e Desobediência civil. Ver, a esse respeito, o bom comentário de Dana Villa: "In her essay 'Civil Desobedience' (1970) she brands Socratic conscientiousness and care for one's soul as 'unpolitical', arguing that his moral rigor is based, ultimately, not on any care for the world, bur on self-interest. The Socratic idea of conscience $[\ldots]$ is presented as the sponsor of a radical withdrawal from de world, the responsibilities of citizenship, and the joys of acting with others. From
} 
cia, que não visa a recobrir a experiência da palavra por uma verdade coercitiva, mas contribuindo de outra maneira para a vida de sua cidade, isento de hostilidades quaisquer aos afazeres humanos. Assim, em ensaios como Algumas questóes de filosofia moral, Pensamento e consideraçóes morais e principalmente desde Filosofia e política, de 1954, ela irá descobrir a pluralidade da condição humana embrionariamente presente no estar só e no retiro socrático consigo mesmo, o famoso diálogo do "dois-em-um", lá onde menos estaríamos propensos a encontrá-la. Afastando-se intermitentemente de concepçóes metafísicas, ela dirá que o pensamento, embora seja uma ocupação solitária e recolhida da presença exterior de outrem, constitui a indicação de uma cisão interna do eu consigo mesmo, em que a única exigência consiste em que o pensador não se contradiga a si mesmo.

Essa pluralidade na atividade do pensar carrega consigo uma distinção entre o isolamento e a solidão. Conquanto a atividade de pensar se exerça em estado no qual "eu me mantenha em companhia de mim mesmo", não é ele um atributo que se dê em solidão, um estado em que, "mesmo estando sozinho, não seja eu capaz de estar acompanhado de mim mesmo". Considerando que o pensar é uma atividade que carrega de modo inerente uma consciência de si que o espreita, é preciso que o eu respeite certos limites, que não se valha de certos subterfúgios que não poderia aceitar, se outros deles também se valessem. Na medida em que todo "ator pensante" está vinculado a uma consciência observadora de si, que o acompanha e testemunha seus ditos e feitos, necessário se faz a ele cuidar de si mesmo, abstendo-se de excessos que poderiam torná-lo estranho e moralmente indigno ao duplo que é. Com efeito, aquele que em seu \poç (éros) respeita o espectador que o vigia incessantemente, haverá de prezar também ao outro e ao mundo que o circunda, sem jamais se sentir em solidão no diálogo sempre renovado do eu consigo mesmo. O pensar pode ser uma atividade retirada e solitária, contudo, seu estado fundamental não é o da solidão, pois se trata de uma circunstância em que o eu faz companhia a si mesmo. Sua "experiência condutora não é a ipseidade [selfhood]", mas a amizade, porque, em sua dualidade, o $₫ \rho \circ \varsigma$ (éros) de Sócrates cura a aparente solidáo do pensamento - tradicional motivo de chacota entre os gregos, desde

the standpoint of the conscientious individual, such withdraw minimizes the possibility of committing acts that jeopardize one's inner harmony, one's continued ability to live with oneself, particularly in moments of thoughtful solitude. Arendt would have us believe that the Socratic idea of moral integrity thus reduces to a kind of selfishness, the result of valuing of our inner harmony above our worldly responsibilities. Socrates loves his soul more than his city, a ranking Arendt considers almost sinful." (VILLA, 1990, p. 209). 
o episódio de Tales e a escrava trácia - ao apontar para a infinita pluralidade que é a característica básica da vita activa na Terra.

Da máxima socrática que ele preferia sofrer o mal a estar em contradição com seu próprio Saí $\mu \omega v$ (daimōn), Hannah Arendt irá retirar as implicaçôes políticas do pensar em sua possível capacidade reflexiva de evitar o mal. Ora, se a relação de si para consigo no pensamento náo se dissocia de uma relação estética para com o mundo na raı́cía (paideía) e governo dos outros, a habilidade de pensar poderá muito bem nos preparar para a tarefa de julgar e discriminar a diferença contingente entre o certo e o errado, o belo e o feio, precavendo-nos contra malefícios públicos. Sem exercer um pensamento que refletisse sobre o espaço da cidade tal qual um objeto, mas no sentido de quem considera e pratica o pensamento como uma atividade de porte político, Sócrates é interpretado como aquele que "trouxe a filosofia dos céus para a Terra", na retomada expressão do senador romano Cícero.

Uma vez que, através de seu questionamento, Sócrates infectava fisicamente seus ouvintes com suas próprias perplexidades, interrompendo quaisquer das atividades habituais, seus parceiros de conversação não mais podiam aplicar mecanicamente regras universais de conduta a casos particulares, como de praxe o faziam. E, se ele assim procedia, era com o fito de converter seus "parceiros-competidores" em amantes de uma sabedoria que lhes transferisse uma apreciação daquilo que esteticamente poderiam antes sentir ou ter em comum (sentido comum estético), afastando os riscos do espírito agonístico (senso privado estético) próprios à democracia grega, aliás, tão criticados à sua maneira por Platão.

O $\unrhd \rho \circ \varsigma$ (éros) socrático, nesse sentido, bem poderia ser diferenciado do

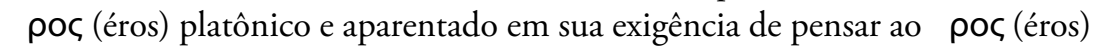
de Hannah Arendt, pois a validade exemplar da causa perdida de Sócrates ao tribunal que o condenou à morte é recuperada por Arendt como o modelo de alguém que paradoxalmente serviu à risca as advertências de Péricles de que seus cidadãos amassem melhor a sua cidade do que a beleza e a sabedoria. ${ }^{8}$ Numa palavra: Sócrates seria o paradigma político maior que protagonizava a atitude iluminista de quem prestava contas e demandava aos outros que

8 No dizer de Dana Villa: "As with Nietzsche, the overarching criterion is aesthetic rather than moral. What matters in Arendt's rendition of Socratic dialectic is the richness of the phenomenal world revealed through the conversation among friends. The (more obviously moral) effect of limiting or restraining the agonal spirit is distinctly secondary. So, we are left with the question of what cause, precisely, the Socratic midwifery of 'Philosophy and Politics' serves." (VILLA, 1990, p. 212-213). 
prestassem contas de suas devidas opinióes, nada obstante seu fracasso em persuadir o tribunal que o condenou à morte; ou seja, o de converter o desprezo ou a indisposição estética de gosto própria daqueles a quem se destinava, seus conterrâneos justamente. ${ }^{?}$

Aliás, fazendo um adendo, tal era a paixão de Hannah Arendt endereçada às causas perdidas que ela chegou a escolher como uma das epígrafes para o que viria a ser o livro sobre a faculdade de julgar, caso a morte não lhe viesse enfim recordar a finitude de sua imaginação, a máxima atribuída a Catão, durante a expedição da Legio tertia decima Geminia de César, na Gália: Victrix causa deis placuit, sed victa Catoni (a causa vitoriosa agradou aos deuses, mas a derrota agrada a Catáo). Normalmente, os vencedores acreditam, como Júlio César, que a história terminou bem, porque a razão da história ou os deuses estariam do seu lado, ao passo que os perdedores se perguntam por que tudo foi diferente. E Hannah Arendt considera que a última é uma questáo muito mais relevante, na medida em que a solução platônica não fora capaz de fazer justiça aos requisitos da palavra pública socrática. Sabe-se que o receio ateniense em relação ao vício bárbaro de um desmedido senão dionisíaco amor ao belo, que afastasse seus cidadãos das preocupações com a пódıc (pólis), justificava-se diante do primado público da vida do cidadão sobre a vida contemplativa dos filósofos.

Por sua vez, recuperando uma vez mais o velho argumento de desprezo e chacota contra os бoyoí (sophoi), Péricles afirmava que Atenas era grande, porque os atenienses se submetiam às demandas legais do mundo público, amando a beleza dentro dos limites do juízo político. Todavia, numa cidade que só continha muros (ou fronteiras, ou leis) ao invés de palavras para demarcar os seus limites, era perene o risco para os amantes da beleza de cederem ao vício bárbaro do excesso e de perderem a civilidade (futuramente em latim, sua civitas), seu caráter viril (sua virs): a possibilidade de discriminação diante do certo e do errado, permanecendo em estado de perpétua sideração. Essa situação de êxtase preocupava os atenienses, ao considerarem que tal condição de

\footnotetext{
9 "Podemos olhar para esse fator da publicidade, necessária ao pensamento crítico, ainda de um outro ponto de vista. De fato, o que Sócrates fez, quando trouxe a filosofia dos céus para a terra e começou a examinar as opiniōes correntes entre os homens, foi extrair de toda afirmação as suas implicaçôes ocultas ou latentes; era com isso que se importava sua maiêutica. Assim como a parteira ajuda a criança a vir à luz para ser examinada, Sócrates traz implicaçóes à luz para serem examinadas. (Foi isso o que Kant fez quando reclamou do progresso: extraiu as implicaçôes desse conceito; foi o que fizemos aqui quando protestamos contra a metáfora orgânica.) Em ampla medida, o pensamento crítico consiste nesse tipo de 'análise'. Esse exame, por sua vez, pressupóe que todos estão dispostos e são capazes de prestar contas do que pensam ou dizem.” (ARENDT, 1993d, p. 54-55).
} 
arrebatamento impedia a capacidade discursiva 入óyoc (lógos) dos indivíduos, a qual se desenvolvia retoricamente em Atenas, de formar opinióes a respeito do bem público. $\mathrm{O}$ amor à sabedoria, então, deveria estar submetido não apenas ao amor pelo belo [ka入óc (kalós)], mas ao amor pela beleza de Atenas; eis o supremo critério a que apelava a "Oração fúnebre" de Péricles.

Ora, na medida em que Sócrates, mediante a dialética tranquilizadora de sua maiêutica, purgava os indivíduos de seus exageros, o sentimento de agonia tão característico aos gregos podia sofrer uma "dessideração" ao se trans-

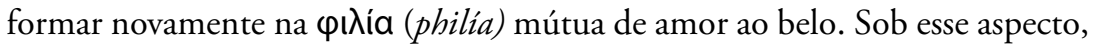

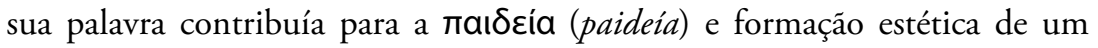
mundo comum a todos, indispensável à compreensão própria e à amizade. Sua descoberta impunha também a introdução do valor político da consciência no domínio dos afazeres mundanos, e o pensamento aparecia como necessário

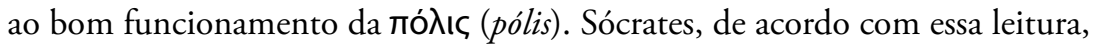
parecia ter acreditado na função política do filósofo em estabelecer os laços de um mundo comum, no qual nenhuma forma constrangedora de governo (que separasse uma minoria reinante da maioria ignara) seria necessária, pautado apenas sobre a compreensão mútua e sobre a amizade. Longe, pois, de contri-

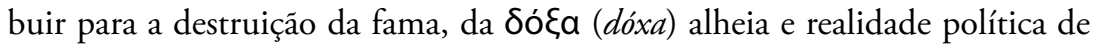
Atenas, a serenidade de sua fala convidava seus interlocutores a se retirarem do isolamento de quem se pretenderia excessiva e distintivamente admirado, tal como o homérico exemplo de Aquiles permanecerá para as futuras geraçóes, retornando ao convívio de um mundo comum, onde se possa compreender (Vernunft) a verdade e respeitar civicamente seus irmáos. ${ }^{10}$

Mas é conveniente também alertarmos o leitor de que esse papel reservado por Sócrates à consciência entrava em conflito com os ditames de Péricles, quando este exigia muito mais o respeito por suas leis do que a consideração pelos direitos secundários de uma consciência pessoal. A procura da verdade

\footnotetext{
10 "A amizade consiste, em grande parte, na verdade, nesse falar sobre algo que os amigos têm em comum. Ao falarem sobre o que têm entre si, isso se torna muito mais comum a eles. Não só o assunto ganha sua articulação específica, mas desenvolve-se, expande-se e finalmente, no decorrer do tempo e da vida, começa a constituir um leque no mundo particular, que é compartilhado na amizade. Em outras palavras, Sócrates tentou tornar amigos os cidadáos de Atenas, e esse foi realmente um objetivo muito compreensível em uma polis cuja vida consistia em uma intensa e ininterrupta competição de todos contra todos, de aei aristeuein, em que, sem cessar, buscava-se demonstrar ser o melhor de todos. Nesse espírito agonístico, que acabaria por levar à ruína as cidades-estado gregas porque tornava quase impossível o estabelecimento de alianças, envenenava-se a vida doméstica dos cidadáos com a inveja e o ódio mútuo (a inveja era o vício nacional da antiga Grécia), o bem público era constantemente ameaçado." (ARENDT, 1987, p. 98).
} 
da $\delta$ óła (dóxa), tal qual Sócrates a perseguia, poderia muito bem conduzir, conforme o ponto de vista da democracia ateniense de Péricles, à simples des-

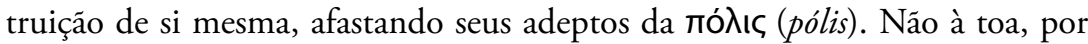
uma espécie de terrível mal-entendido e manifesta ausência de mentalidade alargada, que até nossos dias ainda estrutura o conflito entre filosofia e política, Sócrates fora tragicamente condenado por seus concidadáos a beber cicuta, sob a acusação de corromper politicamente os jovens de Atenas, bem como pela introdução de novos deuses. ${ }^{11}$ Ipso facto, seus diálogos em praça pública eram vistos como de praxe aporéticos, ou seja, não chegavam a uma definição cabal e sistemática, ao conhecimento (Verstand) da verdade sobre questão em pauta. $\mathrm{O}$ mestre da arte obstétrica, ao engajar-se em fazer parir a verdade em outros, nunca afirmou a regra ou um fundamento racional anterior ao seu próprio ato de pensar. Ele ironicamente nada sabia de antemão; ou melhor, era sábio apenas no que tangia aos assuntos de amor, acerca do lugar vazio e público de onde se posicionava para deliberar sobre as questóes mundanas. $\mathrm{O}$ ineditismo de seu Saí $\mu \omega v$ (daimōn) residia justamente em afirmar zombeteiramente a impossibilidade de uma determinação cognitiva da política.

Assim, vê-se que a função do pensamento tal qual executada por Sócrates, longe de conferir uma verdade lógica pautada previamente por suas premissas, terminava, pelo contrário, em atribuir um papel purgativo ao pensamento de seus preconceitos determinantes. Sua esterilidade mesma, sua falta de opinião eram os pré-requisitos para a verdade a ser alcançada na assunção da liberdade de seu pensamento. Diante do fracasso mútuo em determinar-se a contingência do mundo político, ao invés de fornecer um esquema prévio aos conceitos, apontando cognitivamente para a distinção entre verdade e opinião, a arte retórica praticada em praça pública pela maiêutica de Sócrates tinha a

\footnotetext{
11 "A acusação, no julgamento de Sócrates, de que ele introduzia novos deuses na polis foi um pretexto; Sócrates nada ensinou, muito menos novos deuses. Mas a outra acusação, a de que ele corrompia os jovens, não deixava de ter fundamento. $\mathrm{O}$ problema dos homens de pensamento crítico é que eles 'fazem tremer os pilares das verdades mais bem conhecidas onde quer que deitem seus olhos' (Lessing). Este era certamente o caso de Kant. Kant era o destruidor de tudo, muito embora jamais tivesse entrado no espaço do mercado [como Sócrates, diga-se de passagem]." (ARENDT, 1993d, p. 51). Curiosamente também Hegel, à sua maneira, não deixou de frisar o aspecto manifestamente trágico do destino de Sócrates, embora Arendt discordasse que tenhamos logrado erguer um novo mundo que respeitasse enfim os seus princípios: "O destino de Sócrates é [...] autenticamente trágico [...] O princípio do mundo grego ainda não podia suportar o princípio da reflexão subjetiva; então esse segundo princípio apareceu como algo hostil e destrutivo. Assim, o povo ateniense era não só autorizado, mas obrigado a reagir contra isso segundo suas leis; portanto, eles consideravam o princípio da reflexão subjetiva como crime. Essa é a posição dos heróis na história universal em toda parte; por meio deles ergue-se um novo mundo." (HEGEL, 2004, p. 79).
} 
capacidade de humanizar o espaço do convívio humano, dando vazão à discriminação e ao discernimento daquele que julga. Dessa forma, o pensamento crítico ou socrático ${ }^{12}$ (Hannah Arendt chega a usá-los intercambiavelmente, ao explorar suas consequências morais em evitar o mal) exerceria uma função negativa, a qual prepara seu interlocutor para a tarefa de julgar publicamente em liberdade, de ousar pensar corajosamente por si mesmo, sapere aude, e de dizer a verdade. ${ }^{13} \mathrm{Na}$ medida em que nos fornece a estrutura de discernimento para a aceitaçáo ou recusa daquilo que se nos apresenta como necessário, seu pensamento salvaguardaria um atributo político à sua atividade, mesmo limitado negativamente ao sentido profilático de libertar o indivíduo de seus preconceitos inerentes ao âmbito privado e opinativo.

\section{Sócrates E A ACEITAÇÁo da FINITUde}

Vosso mau amor de vós mesmos faz do isolamento um cativeiro.

(Nietzsche, Assim falava Zaratustra)

\footnotetext{
12 "Pensar criticamente, sinalizar a trilha do pensamento em meio aos preconceitos, em meio às opiniôes não examinadas e às crenças, é uma antiga preocupação da filosofia que podemos remeter, enquanto empreendimento consciente, à maiêutica socrática em Atenas. Kant estava cônscio dessa relaçấo. Disse explicitamente que desejava proceder 'no estilo socrático', silenciando todos os críticos 'pela mais clara prova de sua ignorância'. Contrariamente a Sócrates, acreditava em um 'sistema futuro da metafísica', mas o que finalmente legou à posteridade foram críticas, e não um sistema.” E mais adiante na mesma lição: "O estilo socrático foi importante para Kant ainda por uma outra razáo. Sócrates não foi membro de qualquer seita e não fundou nenhuma escola. Tornou-se a figura do filósofo porque desafiou todos os que vinham ao mercado - porque estava completamente desprotegido, aberto a todos os questionadores, a todos os que dele exigissem prestação de contas ou vivência daquilo que dizia." (ARENDT, 1993b, p. 49-50).

${ }^{13}$ Curiosamente, será Michel Foucault, outro pensador contemporâneo decidido a prosseguir a tarefa iluminista aberta por Kant, a explorar, em seu último curso no Collège de France, a questáo do cuidado ético com a palavra, ao problematizar o tema da "coragem de dizer a verdade" socrática. "Here, the listener is led by the Socratic logos into 'giving an account' - 'didonai logon' - of 'himself , of the manner in which he now spends his days, and the kind of life he has live hithertho' [...] Here, giving an account of your life, your bios, is also not give a narrative of the historical events that have taken place in your life, but rather to demonstrate whether you are able to show there is a relation between the rational discourse, the logos, you are able to use, and the way that you live. Socrates is inquiring into the way that logos gives form to a person's style of life; for he is interested in discovering whether there is a harmonic relation between the two. [...] Socrates' role, then, is to ask for a rational accounting of a person's life." (FOUCAULT, 2001, p. 96-97).
} 
Embora a morte de Sócrates tenha adquirido entre nós o significado de enfraquecer o direito antigo dos deuses, sua contradição trágica com os atenienses não pode ser suprimida em nome de uma esfera superior - como desejou Platão, ao substituir a religiáo do Olimpo pelo pensamento do Ser. De acordo com as análises arendtianas, em Filosofia e política, um fator político e cultural pode ser apontado como razão para tamanho paradoxo. A despeito de

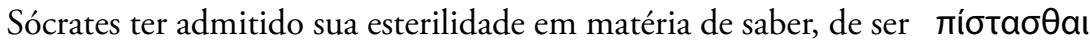

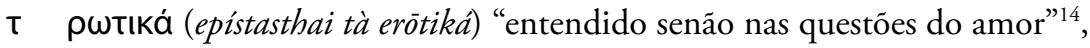
é bastante provável, dirá Arendt, que ele tenha aparecido aos seus concidadáos já como um melindroso пعрıттóc (perittós), perito ou extraordinário expert da verdade em questóes políticas. ${ }^{15}$ Ainda que seu intento jamais tenha sido o de destruir a ठóła (dóxa) e a abertura estética de cada qual ao mundo político, o conflito parece ter irrompido devido aos atenienses terem dado consentimento a tal interpretação de sua postura. Mais uma vez em nossa história, se o maior inimigo da autoridade é o desprezo, como náo se cansa de asseverar Arendt, a maneira mais segura de solapá-la parece ser a chacota. Em outras palavras, por mais que a inserção de seu $₫ \rho \circ$ (éros) tivesse como objetivo maior e louvável o "diálogo antecipado com os outros" - e a concomitante recuperação de um espaço público de $\varphi$ i ía (philía), ao fazer de Atenas uma cidade mais bela -

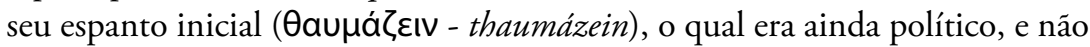
filosófico, fora visto como um despropósito racional, ao tentar tornar a filo-

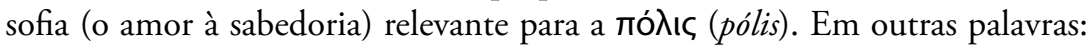
aquilo que, à primeira vista, pareceria distinto ou brilhante filosoficamente pode muito bem não ser louvável politicamente. Tamanho era o desajuste de Sócrates em relação às leis de sua comunidade (único recurso de que dispunham para estabelecer limites ao espírito agonístico que lhes era inerente). Vale dizer novamente: intromissão excessiva do бọóc (sophós) nos assuntos da cidade. ${ }^{16}$ Daí o aspecto trágico e ingrato da posição deslocada de seu $\lambda o ́ \gamma o \varsigma$

\footnotetext{
${ }^{14}$ Cf. Platão (1994, 177d).
}

${ }^{15}$ Retomando no início de seu discurso de defesa as acusaçōes que lhe foram dirigidas no Tribunal de Atenas, Sócrates alega que foi erroneamente confundido com sofistas, tais como Górgias de Leontino, Hípias de Élis, Pródico de Ceos e Eveno de Paros. Este é caracterizado ali como possuidor de um conhecimento a respeito da política e mestre da cidadania. Sócrates procura então distanciar-se da identificação, sustentando que não possui saber algum e jamais se propôs ensinar algo a alguém. Seus argumentos não são, porém, capazes de convencer os atenienses, de maneira que o filósofo é condenado à morte. (PLATÃO, 1980, 19b-20e).

16 "Os atenienses lhe disseram que pensar era subversivo, que o vento do pensamento era um furacão que varria para longe todos os sinais estabelecidos, pelos quais os homens se orientavam no mundo; ele trazia desordens às cidades e confundia os cidadáos, especialmente os jovens. E embora Sócrates negasse que o pensar corrompe, não sustentava que ele aperfeiçoasse, e embora declarasse que 'nenhum 
(lógos), de uma palavra contrária ao ensinamento dos antigos e intimamente ligada ao significado sombrio da existência.

Justamente ele: Sócrates, responsável e distinto cidadão ateniense que, ao contrário do "bom senso" de Aristóteles, anos mais tarde, ao "picar a mula" de Atenas sem qualquer remorso, resolvera cumprir à risca as leis que o haviam sentenciado à morte. ${ }^{17}$ Preferira sofrer o mal e sacrificar um galo a Asclépio a entrar no cativeiro do desacordo consigo mesmo. Ele, que pensava simplesmente em não se contradizer, mantendo-se em consonância e equilíbrio [ $\sigma \omega \varphi \rho o \sigma u ́ v \eta$ (sōphrosýnè)] com o parceiro-espectador que nele residia, até mesmo quando se encontrava a sós. Com efeito, o verdadeiro oposto do sentimento do belo não é o feio, dirá Hannah Arendt, em suas Lições sobre a filosofia política de Kant, mas "aquilo que provoca repugnância", repúdio ou desprezo acrescentamos, em nosso sentido comum estético. E tamanho repúdio dos atenienses à atitude socrática não se deve, entrevemos, senão ao melindre grego diante do convite ao saber que Sócrates formulava aos seus ouvintes, quando não assentia imediatamente à "beleza e à verdade" apolínea de seus discursos. Nesse sentido, acreditamos que o passatempo predileto de Sócrates servia a uma causa política outra do que o puro divertimento de um esteta decidido a seduzir o belo $\pi \mathrm{a} \bigotimes \varsigma$ (pâेs) Alcibíades. ${ }^{18}$

Não obstante, sabe-se que, diferentemente do belo, para quem o gosto pressupóe e mantém o ânimo em serena contemplação, o sentimento do sublime comporta um movimento do ânimo. Enquanto a circunstância da beleza é marcada pelo prazer e harmonia na relaçáo entre as faculdades da imaginação e do entendimento (que nos faz louvar ou refletidamente aprovar o ponto de vista de outrem), no caso do sublime, essa relação é marcada não só pelo prazer, mas também pela dor e desprazer. Ao contrário do sentimento do belo, o qual apresenta o fenômeno na sua finalidade sem fim como tendo uma unidade formal que se entrega à percepção, o sublime esgarça essa unidade,

bem maior acometeu à polis do que aquilo que fazia, não alegava ter começado a sua carreira como filósofo para tornar-se um grande benfeitor." (ARENDT, 2004, p. 246).

${ }^{17}$ Aristóteles foi quem recusou aos atenienses o direito de terem cumprido o duplo assassinato à filosofia, retornando assim à Macedônia, sua terra natal. Já Platão irá utilizar a incapacidade de Sócrates de convencer o tribunal que o sentenciou à morte como objeto de crítica ao modelo democrático ateniense.

${ }^{18}$ É a cáustica pena de Lebrun que temos aqui em mente, ao acentuar, ironicamente, o viés estético da conduta socrática em praça pública. "Este passatempo, cuja futilidade escandalizava os atenienses, tem pelo menos alguma chance de deslindar para o homem o seu fim último? Nem sequer. [...] De que serve, entáo, este divertimento de esteta? De que serve 'pensar em alguma coisa' em vez de esforçar-se por 'conhecer alguma coisa'? Se não for para seduzir o belo Alcibíades." (LEBRUN, 1992, p. 61-62). 
desesquematizando nossos acordos previamente estabelecidos com o mundo. E, como é sabido, o sentimento do sublime também é capaz de suscitar prazer. O prazer proporcionado pelo sublime é resultante de um desprazer inicial provocado pelo confronto entre as duas faculdades em questão: a imaginação e a razão. O malogro da imaginação em representar algo que nos é ininteligivelmente grande revela - mediante um fenômeno estético - uma experiência radical da finitude humana. Ele é, antes, um sentimento que se dá quando o espírito se sente repelido e, logo a seguir, atraído por um objeto; uma disposição e expansão das forças vitais que acontece consecutivamente à inibição provocada inicialmente. À dor, correspondente ao fracasso da imaginaçáo perante a ideia de grandeza incomensurável de um objeto, segue-se inevitavelmente o sentimento do sublime propriamente dito.

Ora, necessitaríamos aqui, então, do mais hercúleo esforço imposto à nossa imaginação para louvar e colocar em discurso a provocação da mais alargada das mentalidades de que já tivemos notícia, em nossa história: Sócrates. Com efeito, a raiz do sentimento de repulsa, que como os atenienses poderíamos endereçar à filosofia, reside justamente no desprazer que sentimos diante da incapacidade de determinar em palavras uma espantosa experiência que, desde Sócrates, nos aparece como "desmedida e absurda" - sem que nos sintamos logo a seguir animados a ultrapassar livremente todo o padráo de medida dos sentidos, unificando-os numa unidade comum.

Extraordinária experiência estética, aliás, cuja derrota exemplar é requerida por Arendt, em sua tentativa de fazer brotar uma nova e autêntica filosofia política, a partir de seu impulso de admiração que se segue à magnitude de Sócrates, diante de sua condenaçáo pública. E a validade de seu exemplo estará restrita justamente àqueles que, de acordo com a disposição estética de seu gosto e vontade, retirarem de sua tragédia uma ferida incurável para nossa civilização - uma experiência particular demais para ser exaltada em qualquer universal de fato. Na expressão de Peter Szondi (2004, p. 85): "Só é trágico o declínio de algo que náo pode declinar, algo cujo desaparecimento deixa uma ferida incurável." ${ }^{19}$ Numa palavra: se a vitória dos atenienses em seu julgamento pudera agradar aos deuses do Olimpo, a derrota de Sócrates diante do mesmo tribunal agradara a Arendt; entretanto, não a Platão, certamente...

Assim, dirá a insigne dama weimariana que esse choque inicial do qual não apenas Sócrates é acometido, mas que, em sua singularidade, todo ho-

${ }^{19}$ Deliberadamente, reservaremos para um trabalho posterior os corolários arendtianos da suposta tragédia de Sócrates. 
mem experimenta como um universal fugidio, esse estado mudo em que um dos aspectos básicos da condição humana em face da Terra se revela (estado particular para o qual, na fuga do universal, o sentimento resultante é sempre o do trágico), "não pode ser relatado em palavras, por ser geral demais para palavras" (ARENDT, 1987, p. 111). Por não se encontrarem preparados para compreender e aceitar a ironia presente na sentença que Sócrates recebera do oráculo de Delfos, "Só sei que nada sei", essa atitude original de espanto, a qual traduz ironicamente a impossibilidade de obter-se, em termos de conhecimento (Verstand), uma resposta científica para os assuntos mundanos, fora encarada pelos seus coetâneos, quer por má-fé, quer por pura estupidez, como

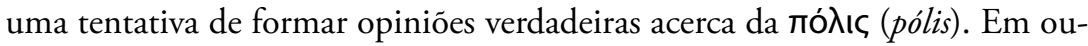

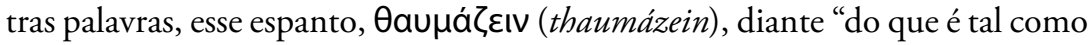
é" - que posteriormente Platão e Aristóteles irão se recusar a conceder à esfera dos assuntos humanos, destruindo a faísca da embrionária pluralidade da condição humana - aparece contrariamente para Arendt protagonizado por Sócrates como a marca maior de seu modus vivendi político. ${ }^{20}$

Ora, mas se Sócrates não desejara ainda, como Platão, fazer da filosofia

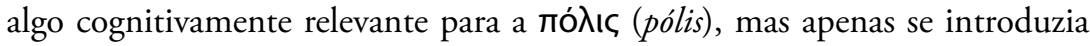

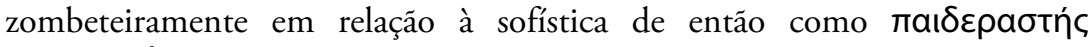
(paiderastếs), amante nos assuntos públicos, é óbvio que não poderemos mais considerar o espanto filosófico próprio ao seu $\delta$ aí $\mu \omega v$ (daimōn) - sua

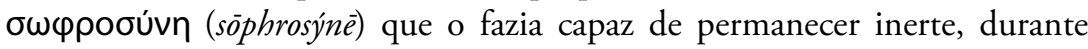
horas a fio, considerando um problema sem chegar a uma conclusão satisfatória - como uma atividade puramente contemplativa que se opusesse substancialmente à ação. ${ }^{21}$ Distintamente do pensamento especulativo e filosófico, o pensamento tal qual praticado por Arendt, a partir de seu modelo socrático, não rompe os laços com o mundo das aparências, mas o prende diretamente à esfera dos assuntos humanos, estreitando seus vínculos com o

20 "Sócrates, apesar de protestar sempre que não possuía nenhuma verdade ensinável, já devia, de algum modo, ter aparecido como um perito na verdade. $\mathrm{O}$ abismo entre verdade e opiniáo, que daí por diante viria a separar o filósofo de todos os outros homens, ainda não fora aberto, mas já estava indicado, ou melhor, prenunciado na figura desse único homem que onde quer que fosse tentava fazer com que todos à sua volta, e antes de tudo ele mesmo, ficassem mais verdadeiros. Em outras palavras, o conflito entre filosofia e política, entre o filósofo e a polis, irrompeu não porque Sócrates quisesse desempenhar um papel político, mas antes porque queria tornar a filosofia relevante para a polis. [...] A verdade, por outro lado, é que surgiu na pessoa e no julgamento de Sócrates uma outra contradição entre filosofia e política, muito mais profunda do que indicam aparentemente os ensinamentos do próprio Sócrates." (ARENDT, 1987, p. 105-106).

${ }^{21}$ Recorde-se, a respeito, a coragem exibida por Sócrates na batalha de Delium. 
ato de julgar. Dirá Hannah Arendt que é dessa sublime ${ }^{22}$ e muda experiência de nada saber que nascem as perguntas últimas da filosofia introduzidas desde a

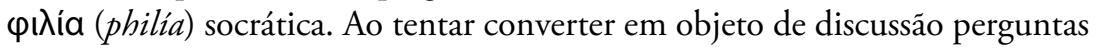
últimas e irrespondíveis acerca das virtudes políticas, Sócrates encontrava uma voz que ressoasse no mundo que o circundava, ao discutir com seus amigos questôes que não se limitavam ao foro íntimo, mas se estendiam ao foro de juízo comum: a ágora pública. ${ }^{23}$ Isso significa que passamos a estar aptos a fazer abstração de todas essas circunstâncias e condiçóes privadas que, quanto ao juízo e à atuação diante dos outros, "limitam e inibem seu exercício" em interesse próprio. Caso não fizermos tal operação intelectual de direito, quid juris, a política permanecerá uma preocupação filosófica em interesse de uma minoria reinante em oposição à maioria ignara do $\delta \nabla \mu \circ \varsigma$ (de凶冈mos). Para Arendt, assim como para Sócrates e também para Kant, o problema filosófico fundamental só aparece justamente quando essa hierarquia desaparece.

A maneira, inclusive, como o procedimento maiêutico é apresentado nos textos de Arendt náo deixa de se aparentar fortemente à ideia de pensamento representativo e mentalidade alargada que ela irá retirar de Kant, de sorte a descrever como se forma uma opinião imparcial, necessária à prática do 入óyoc (lógos) em interesse republicano pelo mundo. Curiosamente, também em Kant poderíamos notar a insurgência contra a distinção que opóe a

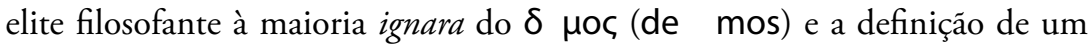
espectador crítico que, por mais afastado que esteja do espírito agonístico e do engajamento, nem por isso se declara portador de uma verdade contemplada, restrita à comunicaçáo e avessa à pluralidade humana. Pelo contrário, tratar-se-ia, tanto para Kant como para Sócrates, da coragem de se pensar sem amparos ou doutrinas, de imaginar antecipadamente ou com mentalidade

${ }^{22}$ Num ensaio sobre a amizade de Lessing, Arendt salienta: “Tudo o que não possa se converter em objeto de discurso - o realmente sublime, o realmente horrível ou o misterioso - pode encontrar uma voz humana com a qual ressoe no mundo, mas não é exatamente humano. Humanizamos o que ocorre no mundo e em nós mesmos apenas ao falar disso, e no curso da fala aprendemos a ser humanos." (ARENDT, 1987, p. 31).

23 'Se 'uma vida não examinada não vale a pena ser vivida', então o pensar acompanha o viver quando se preocupa com alguns conceitos como justiça, felicidade, temperança, prazer, com palavras para coisas invisíveis que a linguagem nos ofereceu para expressar o significado de tudo o que acontece na vida e nos ocorre enquanto estamos vivos. Sócrates dá a essa busca o nome de eros, um tipo de amor que é primariamente uma necessidade - ele deseja o que não tem - e que é a única questão em que se diz especialista." (ARENDT, 2004, p.246). 
alargada o julgamento possível de todos os outros, a fim de tornar manifesto o pensamento por meio do juízo. ${ }^{24}$

\section{4 À GUISA DE CONCLUSÁo}

Os únicos objetos destituídos de fim são os objetos estéticos, por um lado, e os homens, por outro. Deles não podemos perguntar com que finalidade? Para que servem? Pois não servem para nada. Mas a ausência de fim da arte tem o "fim" de fazer com que os homens se sintam em casa no mundo.

(Hannah Arendt)

Não restasse agora um pormenor sujeito ainda a mal-entendidos, seria reconfortante providenciar, enfim, um desfecho satisfatório a este denso artigo. Ipso facto, assim não procederemos. Com o fito de exercer não apenas uma "apropriação simplificadora de outrem a fins de comunicação", porém, "uma experiência modificadora de si no jogo da verdade"25, consideremos o comentário do professor Gérard Lebrun, em seu acrimonioso Hannah Arendt: um testamento socrático:

Pensar, para H. Arendt, é assegurarmos que estamos em conexão com nosso superego... É esta exigência que torna inteligível o paradoxo socrático: 'Mais vale sofrer que cometer a injustiça.' [...] E o imperativo categórico, acrescenta Arendt, apenas reformula esta prescrição. Nunca contradigas a ti mesmo. "[...] Nunca faças exceção em teu proveito." Sendo assim, ele

\footnotetext{
${ }^{24}$ São vários os textos nos quais se pode observar uma fidelidade arendtiana à concepção kantiana de pensamento alargado. Náo se trata simplesmente de pensar com os outros empíricos - e a posiçáo de Sócrates também está longe de se limitar a isso -, mas de procurar um acordo de princípio que não coincida com o acordo de fato. $\mathrm{O}$ Gemeinsinn, senso comum, presente tanto no diálogo interior quanto no diálogo com outrem, constitui esse princípio da inter-subjetividade ao qual se deve abrir qualquer juízo particular; todavia, trata-se de uma inter-subjetividade transcendental que precede qualquer acordo empírico e sensível entre vários indivíduos. Hannah Arendt alarga por sua própria conta e risco a definiçấo de juízo e senso comum, sem, contudo, demandar a necessidade a priori de um gosto cuja regra serviria como função regulativa. A subjetividade do acordo consigo mesmo consiste no acordo possível de eu com outrem, permanecendo aberto à contingência da alteridade que o fundamenta e limita suas pretensóes. $\mathrm{O}$ pensamento alargado manifesta a modalidade do acordo com o qual se percebe a distância que une e separa o pensamento solitário do eu e o sentido comum que os atravessa.

${ }^{25}$ Confessamos agora nosso alinhamento com o espírito ensaístico de uma escrita, prova de verdade, inaugurada pelo pensador francês Michel Foucault (FOUCAULT, 1998, p. 13).
} 
na seqüência adverte: "Devemos concluir, daí, que Hannah Arendt reduza 'o pensamento' à consciência da Lei Moral? Não. É, antes, à fonte da Lei Moral que ela pretende fazer-nos remontar - à exigência solitária e espontânea que desabrochará na Moralität." (LEBRUN, 1992, p. 62).

Com efeito, Hannah Arendt não deixou em sua obra, alusivamente em algumas passagens, de associar a atividade do pensar socrático à insistência kantiana nos deveres "superegoicos" para consigo mesmo e à fonte de uma lei moral fundada a priori. ${ }^{26} \mathrm{O}$ que fazia Sócrates, portanto, era tornar público, no discurso, o diálogo sem som que mantinha com a consciência moral de si. "Ele atuou no espaço do mercado, assim como o flautista atua em um banquete." ${ }^{27}$ Pois bem, sabe-se que a interrogação filosófica kantiana "O que devo fazer?", assim como as demais questóes críticas "O que posso conhecer?” e "O que me é dado esperar?" sequer mencionam a condição da pluralidade humana. Ademais, às primeiras três Kant costumava acrescentar uma quarta: "O que é o homem?", explicando em sua Lógica que se poderia chamá-las todas de "antropologia" pois remetiam à última. Isso posto, é preciso não perder de vista que a noção subjacente às três questôes reside no interesse próprio e solitário do homem; entrementes, a lição de filosofia política que Arendt retira do projeto crítico kantiano adverte justamente para a abertura desse “interesse” pelo mundo, condição espontânea da pluralidade. Destarte, se o que interessa na arte do pensamento crítico, seja socrático, seja kantiano, são suas implicaçôes políticas ou antropológicas, poderíamos arrematar silogisticamente este argumento, asseverando que o pensar permanece sendo a condição transcendental e publicitária para o exercício reflexivo prévio ao juízo que se abre ao interesse pelo mundo - a despeito de aplicar, segundo Lebrun, regras em interesse próprio (superegoico) que não se abram ao mundo contingente, tal como a lei moral determinante.

${ }^{26}$ Cf. Terceira Lição das LFPK, (ARENDT, 1993b, p. 29).

27 “É pura atuação, pura atividade. E assim como o flautista tem que seguir certas regras para atuar bem, Sócrates descobriu a única regra que governa os rumos do pensamento - a regra de consistência (como Kant a chamaria na Crítica do juizo), ou, como mais tarde a chamamos, o axioma da não-contradição. Este axioma, que para Sócrates era 'tanto lógico' ('Não fale ou pense contrasensos') quanto ético (É melhor discordar das multidôes do que sendo um, estar em desacordo comigo mesmo, isto é, contradizer-me'), tornou-se, com Aristóteles, o primeiro princípio do pensamento, mas apenas do pensamento. Com Kant, entretanto, ele voltou a ser novamente parte da ética, pois a totalidade de seu ensinamento moral repousa, de fato, sobre ele; em Kant, a ética também está baseada em um processo de pensamento: aja de maneira tal que possa desejar que a máxima de sua ação tornese uma lei geral, isto é, uma lei à qual você também se submeteria. Novamente é a mesma regra geral que determina tanto a açấo quanto o pensamento.” (ARENDT, 1993b, p. 50). 
Ora, se o pensamento socrático em seu "dois-em-um" não restringe, como o imperativo categórico, a condição da pluralidade em face da Terra ao mínimo, mas espontaneamente respeita a condição plural da humanidade, por essa razão mesma não acreditamos que ele teleologicamente "desabrochará na Moralität" da finalidade prática, porque isso nos custaria o preço de admitir implicitamente que o juízo teria por fim a função de cópula entre as faculdades teórica e prática (no sentido kantiano) do homem, bem como de associarmos o conceito fenomenológico de ação arendtiano com a concepção prática e moral kantiana. Somente com a referência de uma visada retrospectiva do historiador-observador, poderíamos sustentar que exista tal progresso orientado na moralidade ocidental que conectasse de tal forma o pensar ao julgar; desconsiderando os atributos concedidos por Arendt à noção de agir entre seus pares, ${ }^{28}$ e que Sócrates representasse desde sempre a condição de sua realização prática, fazendo-nos remontar à "fonte imemorial e espontânea" do imperativo categórico. Em tal crença teleológica e idealista Hannah Arendt jamais poderia consentir, ainda que Kant acreditasse regulativamente numa "astúcia secreta da natureza" e Lebrun enxergasse nessa mesma astúcia uma escatologia para a moral. ${ }^{29}$

Declaramos "não poderia consentir", na medida em que a relação entre as três Críticas e a Antropologia, tal como interpretada politicamente por Aren$\mathrm{dt}$, não pressupóe uma imagem concreta do homem que teria comandado a experiência crítica, como se pudéssemos definir a priori a regra de um gosto que a tivesse orientado secreta e racionalmente. Na verdade, se acaso houvesse tal relação obscura de finalidade entre as Críticas e uma imagem inalterável do homem (em que Hannah Arendt jamais acreditou), ela já seria efeito de uma

\footnotetext{
28 'Em primeiro lugar, o 'pensamento alargado' é o resultado da 'abstração das limitaçôes que contingentemente prendem-se ao nosso próprio juízo', é o resultado da desconsideração de suas 'condiçōes subjetivas e privadas', isto é, da desconsideração do que usualmente chamamos de interesse próprio; este interesse, de acordo com Kant, não é nem esclarecido nem capaz de esclarecimento, mas é limitante. Quanto maior o alcance - quanto mais amplo é o domínio em que o indivíduo esclarecido é capaz de mover-se de um ponto de vista a outro - mais 'geral' será esse pensamento. [...] Acabamos de falar deste último em termos de imparcialidade; é um ponto de vista a partir do qual consideramos, observamos, formamos juízos, ou, como diz Kant, refletimos sobre os assuntos humanos. Ele não nos diz como agir. Nem mesmo diz como aplicar a sabedoria - que é encontrada quando se ocupa 'um ponto de vista geral' - aos particulares da vida política. [...] Kant nos diz como levar os outros em consideração; ele não nos diz como nos associar a eles para agir. O que nos leva à questão: esse ponto de vista geral é apenas o ponto de vista do espectador?” (ARENDT, 1993b, p. 57-58).

${ }^{29}$ Cf. Uma escatologia para a moral, de Lebrun, onde este afirma que é a Kant, e náo a Hegel, que devemos uma filosofia da história. Interpretação, diga-se de passagem, bastante contrária à lecionada por Arendt, em suas Liçóes sobre a filosofia política de Kant.
} 
ilusão transcendental, ao se tentar tratar a natureza humana como objeto de uma ciência política. Contudo, registre-se que tal foi a leitura do professor Lebrun, ao afirmar que Arendt tenha assimilado as faculdades do espírito à estrutura inalterável de "uma natureza humana imemorial", cuja verdade seria “consubstancial” ao $\Downarrow v \theta \rho \omega \pi$ о (ánthrōpos) ocidental. ${ }^{30} \mathrm{E}$ se, de fato ou de direito, as coisas fossem dessa maneira, seria mesmo fácil para Arendt "assim jogar fora a razão teórica, e conservar a 'necessidade' ou 'o interesse' da razão". Definitivamente, tal não era a convicção política dela, metodologicamente inassimilável ao jusnaturalismo e a projetos neo-hegelianos da atualidade.

A título de conclusão, a personagem de Sócrates, enquanto "cidadão entre outros cidadãos" na $\pi$ ó ıs (pólis) de Atenas, protagonizou o paradigma de um pensamento que se faz presente como um "ator-espectador" na política. Dado que apenas um pensamento que esteticamente abra sua imaginação, seu entendimento e sua sensibilidade ao juízo, para os eventos do mundo em sua particularidade concreta, seria capaz de reconhecer os momentos críticos de perigo político e evitar "soluçôes" moralmente catastróficas. Entendido como antecedente da ação a ser tomada entre seus pares, seu pensar não deixaria, portanto, de ser uma forma de visar à ação sempre entre seus concidadãos, no mundo plural (mas jamais entre seres inteligíveis, afastados do senso comum estético e do convívio humano, tais como anjos, homens de vontade boa e racional, psicóticos desprovidos de senso comum, fadas ou gnomos...). Foi através desse comportamento socrático que Hannah Arendt persistiu em acreditar retirar a intuição exemplar que lhe possibilitasse a recuperação da base fenomenal esquecida das faculdades do espírito pela tradição, respondendo assim à configuração instrumental de meios e fins, entre o pensamento e a ação assumida desde a modernidade.

Nesse registro, reformulada a faculdade do pensamento e do juízo como domínios reflexivos, diante de seu denegrimento como saberes teórico-cognitivos, resgatar-se-ia uma atribuição ativa ao juízo, cuja validade independe de qualquer sanção moral, e que só pode ser avaliada pelo espectador da cena política, respeitando-se o princípio transcendental da publicidade.

\footnotetext{
30 "Também se sente espanto, frente à idéia de que o germe da razão prática possa ser alojado, sem maiores cerimônias, numa natureza humana imemorial. [...] Desta maneira Hannah Arendt pode saudar ao mesmo tempo o falecimento da metafísica e o triunfo da razáo prática. O que não oferece dificuldade alguma, se é verdade que a razão prática é uma estrutura inalterável do ser humano, que o 'cientificismo' dos filósofos teria camuflado, antes de Kant, e também depois dele. Tal é a convicção de Hannah Arendt (tal é também, mutatis mutandis, a de Habermas). Resta saber se é tão fácil assim jogar fora a razão teórica, e conservar a 'necessidade' ou 'o interesse' da razão." (LEBRUN, 1992, p. 64-65).
} 
BACH, A.; ORLANDI, J. Socrates and Arendt: beyond the political framework. Trans/ form/ação, Marília, v. 42, n. 4, p. 201-222, Out./Dez., 2019.

\begin{abstract}
In order to understand Arendt's conceptions of history and political judgment, this article discusses her peculiar interpretation of Socrates. As with her other ideas, such as the banality of evil, the nature of totalitarian terror, and the public space, her portrayal of the Greek philosopher demands that we discriminate between thinking and acting. Would judgment by chance be the bridge between the activities of thought and political action? My aim in this essay is to show how Arendt, from beginning of her work, was looking for an authentic mode of political life, the major example of which is Socrates. I also address what Arendt meant by her idea of a reflexive judgment, an idea that has proved enormously suggestive yet which remains elusive.
\end{abstract}

KeYwords: Politics. Arendt. Philosophy. History.

\title{
REFERÊNCIAS
}

ARENDT, H. Homens em tempos sombrios. São Paulo: Companhia das Letras, 1987.

ARENDT, H. A dignidade da política: ensaios e conferências. Rio de Janeiro: RelumeDumará, 1993a.

ARENDT, H. Liçôes sobre a filosofia politica de Kant. Rio de Janeiro: Relume-Dumará, $1993 \mathrm{~b}$.

ARENDT, H. Entre o passado e o futuro. São Paulo: Perspectiva, 2003.

ARENDT, H. Responsabilidade e julgamento. São Paulo: Companhia das Letras, 2004.

DUARTE, A. M. O Pensamento à sombra da ruptura: política e filosofia em Hannah Arendt. São Paulo: Paz e Terra, 2000.

FOUCAULT, M. História da sexualidade II: o uso dos prazeres. Rio de Janeiro: Graal, 1998.

FOUCAULT, M. Fearless speeach. Edited by Joseph Pearson. California: Semiotext(e), 2001.

FOUCAULT, M. Introdução à antropologia de Kant. Tese complementar de doutorado em Letras (inédito). (Pode-se consultar o microfilme da tese na Bibliotèque de la Sorbonne sob a côte FB506).

HEGEL, Conferências sobre história da filosofia. In: SZONDI, P. Ensaios sobre o trágico. Rio de Janeiro: Jorge Zahar, 2004. p. 79.

LACAN, J. O seminário VIII: a transferência. Rio de Janeiro: Jorge Zahar, 1992. 
LAFER, C. Na confluência entre o pensar e o agir: sobre uma experiência com os conceitos de Hannah Arendt em A banalizaçáo da violência: a atualidade do pensamento de Hannah Arendt. Rio de Janeiro: Relume Dumará, 2004.

LEBRUN, G. Hannah Arendt: um testamento socrático em Passeios ao léu. São Paulo: Brasiliense, 1992.

LEBRUN, G. Uma escatologia para a moral em Kant: ideia de uma história universal de um ponto de vista cosmopolita. Organização Ricardo Ribeiro Terra. São Paulo: Martins Fontes, 2004.

PLATÃO. Apologia de Sócrates, Critão, Menão, Hípias Maior e outros. Tradução de Carlos Alberto Nunes. Belém: EDUFPA, 1980.

PLATÃO. O Banquete. São Paulo: Abril Cultural, 1994. (Os Pensadores).

RIBEIRO, R. J. A sociedade contra o social: o alto custo da vida pública no Brasil. São Paulo: Companhia das Letras, 2000.

SZONDI, P. Ensaios sobre o trágico. Rio de Janeiro: Jorge Zahar, 2004.

VILLA, D. R. Politics, philosophy, terror: essays on the thought of Hannah Arendt. Princeton: Princeton University Press, 1990.

WAGNER, E. S. Hannah Arendt: ética e política. São Paulo: Ateliê, 2006.

Recebido: 11/07/2016

Aceito: 16/06/2017 